Sign Systems Studies 49(3/4), 2021, 338-360

\title{
Notes on the semiotics of face recognition
}

\author{
Remo Gramigna, ${ }^{1}$ Cristina Voto ${ }^{2}$
}

\begin{abstract}
Perceiving and recognizing others via their faces is of pivotal importance. The ability to perceive others in the environment - to discern between friends and foes, selves and others - as well as to detect and seek to predict their possible moves, plans, and intentions, is a set of skills that has proved to be essential in the evolutionary history of humankind. The aim of this study is to explore the subject of face recognition as a semiotic phenomenon. The scope of this inquiry is limited to face perception by the human species. The human face is analysed on the threshold between biological processes and cultural processes. We argue that the recognition of likenesses has a socio-cultural dimension that should not be overlooked. By drawing on Georg Lichtenberg's remarks on physiognomy, we discuss the critique of the semiotic bias, the association of ideas, and the mechanism of typification involved in face recognition. Face typification is discussed against the background of face recognition and face identification. We take them as three gradients of meaning that map out a network of relationships concerning different cognitive operations that are at stake when dealing with the recognition of faces.
\end{abstract}

Keywords: face recognition; personal identification; semiotics of the face; semiotics of recognition; face perception

\section{Theoretical premises: The perception of human faces ${ }^{3}$}

The fascination with the study of the human face shows its constancy in the history of humanity. Although the face is a visible element of the anatomy and appearance of the human species, it remains a quite enigmatic object and very difficult to fathom. From ancient treatises on physiognomy or physiognomics to the ubiquity

1 Department of Philosophy and Education Sciences, University of Turin, Torino, Italy; e-mail: remo.gramigna@unito.it.

2 Department of Philosophy and Education Sciences, University of Turin, Torino, Italy/ Department of Arts and Culture, Universidad Nacional de Tres de Febrero, Argentina; e-mail: cristina.voto@unito.it.

3 Sections 1, 2 and 3 were written by Remo Gramigna. Section 4 was written by Cristina Voto, except for the first and last paragraphs. Sections 5 and 6 were written in tandem by the authors. 
of automated face detection (Kosinski 2021) much in vogue in today's "culture of surveillance" (Gates 2011), the face remains a subject of profound interest that cuts across numerous disciplines, from evolutionary biology to artificial intelligence. ${ }^{4}$

Our major task in this introductory section is to outline those theoretical premises engendered in us by reviewing the recent literature on the perception and recognition of faces. Because the face is often the object of interpretations, semiotics - thought of as the discipline geared upon the interpretation of signs is one amongst the humanistic disciplines called on to discuss the significance of human faces in all their forms and representations.

Hence, the thrust of this study lies in the semiotics of face recognition. As face recognition is a broad area of inquiry, it is important to establish from the outset the limits of the present research. Firstly, this study is limited to face perception by the human species (for reviews on face perception by nonhuman species, see Leopold and Rhodes 2010). Secondly, in what follows, we do not engage with the concept of recognition as a philosophical issue, as did, for instance, Paul Ricoeur (2005), who pointed out twenty-four different ways of defining recognition. Therefore, concepts such as recognition as 'acknowledgment,' 'mutual recognition' or 'self-recognition' fall outside the limits of the present inquiry. This study is concerned with face recognition as a phenomenon of perception with a particular interest in the semiotic aspects of this phenomenon. The purpose of the study is to map out a network of neighbouring concepts that pinpoint the ramifications of face recognition for semiotics. The paper revolves around three ways of interpreting the human face: recognition, typification and identification. These three aspects set out the three main sections of the study. In what follows we will map out some ramifications of these phenomena.

One of the linchpins of face perception is identity. Indeed, the face is the visible heart of the individual's identity. Jurgen Ruesch (1959:171) defines the face as the signifier par excellence, Ray Birdwhistell (1970) as a "message board", Max Thorek (1946: 1) as an "advertisement to the world", and Jordan Peterson highlights the face as a "broadcast screen". Indeed, information broadcast through the face is multilayered. A whole host of different stimuli are elicited through the face and perceived by others, who constantly monitor faces in others to decode facial stimuli in terms of cues of various nature and as having different meanings (Ekman 1978).

4 On physiognomy and semiotics, see Eco 1975a, Manetti 1993: 84-87, and Magli 1995. For an account on the face from a semiotic perspective, see Fabbri 1995 and Bouissac 2005 (available as Paul Bouissac What is a trustworthy face? at https://semioticon.com/virtuals/risk/ Trustworthyface.pdf).

5 Online lecture: https://www.youtube.com/watch?v=AVPDAa7hymo was accessed on 2 March, 2021. 
Identity, gender, age, skin pigmentation, health, basic emotions, micro-expressions, intentions and much more information is displayed and expressed - either willingly or unwillingly, inferred and decoded - accurately or less accurately, by those who engage in social settings. ${ }^{6}$ Darwin (1872) held that facial expressions in humans have something in common with other animals. Later thinkers sought to identify a possible grammar of emotions through the study of facial expressions (Le Brun 1992; Damish 1992).

Since antiquity, "medical semiotics" (Sebeok 1972) as well as physiognomy identified the human face as a significant subject of interest as witnessed by the long-lasting tradition of Arabic and occidental treatises on physiognomy. ${ }^{7}$ Indeed, there is plenty of historical evidence showing that signs of the face, so to speak, were treated and interpreted as symptoms of certain diseases, as epitomized in Hippocrates. Ancient physiognomy went even further in claiming that there exists an ability to identify the soul and the heart of an individual based on the shape and the nature of the human body and, especially, the face. This idea is later taken up and epitomized in the theory detailed in Johann Kaspar Lavater's physiognomy.

The physiognomic approach, thus, is based on deductive reasoning for it posits that the internal characteristics of an individual can be deduced from the exterior attributes. As Giovanni Gurisatti (2006: 22) rightly pointed out,

[...] between external and internal, sign and what it stands for, there is a staticlocal causal relationship (dual, successive), where the symptom, the spasm, the colour, are nothing but the external effect, the externalization of an internal cause, to which they refer according to a stable and rigorously determined hierarchical scheme. $^{8}$

For this reason, the basis of medical semiotics and physiognomy in interpreting faces and bodily symptoms is a tendency towards "typifying" (Gurisatti 2006: 22). In other words, this branch of medicine sought to identify causes from symptoms by means of a scientific or pseudo-scientific method. As we will see in what

6 The term 'expression' has two semantic components: one subjective and intentional and another objective and non-intentional. On this distinction, see Gurisatti 2006: 26-27.

7 On the tradition of Arabic physiognomy, see Mourad 1939; on Mesopotamian physiognomy, see Bottéro 1974. For an overview of the history of physiognomics, see Antonini 1900; Getrevi 1991; Gurisatti 1991, 2006; Magli 1995; Courtine and Horoche 1992 - they all offer valuable bibliographical sources on the subject.

8 "[...] fra esterno e interno, segno e designato corre qui un rapporto statico-locale causale (duale, successivo), dove il sintomo, lo spasmo, il colore altro non sono che l'effetto esteriore, l'esteriorizzazione di una causa interiore, cui essi rinviano secondo uno schema gerarchico stabile e rigorosamente determinato". All translations from Italian are by Remo Gramigna, unless otherwise noted. 
follows, not only was such a tendency towards typification at the basis of medical semiotics - identifying symptoms on the basis of a type - and some branches of physiognomy, but it also resurfaces today under various guises.

Physiognomy never achieved a scientific status and today it has lost its grip. As Carlo Ginzburg (1986: 170) pointed out, "the flaw of physiognomy was to tackle the variety of individuals in the light of preconceived opinions and hasty conjectures: in this way it has so far been impossible to establish a scientific, descriptive physiognomy". ${ }^{9}$ It is, however, important to recognize that ancient practices of deciphering and reading faces played a pivotal role in what Ginzburg (1986) termed as the 'evidential paradigm' ('il paradigma indiziario') and have a connection with the history of semiotics. In this regard, it suffices to mention the inclusion of scholars such as Lavater on physiognomics and Darwin's study on the face in the history of semiotics (Eco 1984).

Whilst it is visible to others, unless it is masked or disguised, the face is invisible to the subject. Indeed, the face has a twofold character: the face as seer and the face as seen. Tim Ingold (2002: 124) writes,

As a surface, the face has some very peculiar properties. I can feel my own face, and others can see it. But it remains invisible to me. Where others see my face, I see the world. Thus, the face is a visible appearance, in others' eyes, of my own subjective presence as an agent of perception. It is, if you will, the look of human being.

Thus, the human face is the element of appearance which makes the social bond possible through the responsibility that each individual takes in respect to the outer world, which is the principle of personal identity (Le Breton 2010: 72). Given the centrality that the face takes on in social settings (Goffman 1956, 1967; Edkins 2015) and in the definition of one's own identity (Belting 2017), it is not surprising to find a tight connection between the perception of the human face, the recognition of faces by others, and the pivotal role that such processes play in human interactions and the perception of the environment.

It is worth noting that the twofold dimension intrinsic to the concept of the face is apparent in the etymology of the word, ${ }^{10}$ where the duplet seeing/being seen permeates the semantic field of the term 'face' itself. In the Latin tradition, 'vultus'

9 "L'errore della fisiognomica è stato quello di affrontare la varietà degli individui alla luce di opinioni preconcette e di congetture affrettate: in questo modo è stato finora impossibile fondare una fisiognomica scientifica, descrittiva."

10 The idea of perceiving and seeing one's own face is one aspect of the issue and leads to the investigation of the role of mirror and self-reflection in the perception of oneself. Classic studies that deal with this issue from the perspective of semiotics are Eco 2010, Nöth 1990 and Galassi and De Michiel 1997. Also, Baltrušaitis 1981 is very relevant to this debate. 
was used to refer to the variable and changing aspect of the face, whilst the word 'facies' referred to the fixed and immutable physiognomic traits. It is revealing that Isidore of Seville pointed out that the face (facies) is said to be so only because it makes one person recognizable from another and, therefore, allows the identification of a particular individual amongst the crowd (Piras 2010: 48). Indeed, slaves in Ancient Greece were faceless as the word 'aproposon' suggests ${ }^{11}$ (Agamben 2021).

In one etymological explanation of the Latin ' $v u l t u s$ ', the term is traced back to the root 'uel-, vedere'. Hence, 'vultus' refers both to the ability of the individual to see and to be seen (Piras 2010: 53). This aspect also surfaces in the German word 'Gesicht' which encapsulates both meanings. Husserl's phenomenology states this principle very neatly: one element of the face boils down to its visibility, namely, the element of being seen and being perceived from outside perspectives (Husserl 1965: 432). As Agamben (2021) rightly pointed out:

Of course, all living beings show themselves and communicate with each other, but only man makes the face the place of his recognition and his truth, man is the animal that recognizes his own face in the mirror and mirrors and recognizes himself in the face of the other. In this sense, the face is both similitas, similitude and simultas, the being together of men. A faceless man is necessarily alone. This is why the face is the place of politics. ${ }^{12}$

Given the relevance of the element of appearance - showing and being perceived by others - it goes without saying that the opposite tendency - hiding, dissimulating, masking - must be considered in the management of one's appearance. Indeed, the reverse mechanism of recognition is masking, for it hampers the possibility of recognizing another by altering the distinctive facial traits of the person who wears a mask (Ogibenin 1975). Here we come full circle through the opposite mechanism that serves as a cornerstone of the management of appearance: the simulation and dissimulation of one's face. ${ }^{13}$

11 Agamben, Giorgio 2021. Il volto e la morte. Quodlibet, 3 May, 2021 (https://www.quodlibet. it/una-voce-giorgio-agamben). First published in German as "Wo das Gesicht verschwindet", Neue Zürcher Zeitung, 29 April 2021; now also in Agamben 2021.

12 Original in Italian: "Certo tutti gli esseri viventi si mostrano e comunicano gli uni agli altri, ma solo l'uomo fa del volto il luogo del suo riconoscimento e della sua verità, l'uomo è l'animale che riconosce il suo volto allo specchio e si specchia e riconosce nel volto dellaltro. Il volto è, in questo senso, tanto la similitas, la somiglianza che la simultas, l'essere insieme degli uomini. Un uomo senza volto è necessariamente solo. Per questo il volto è il luogo della politica.” Agamben 2021 was accessed at https://www.quodlibet.it/giorgio-agamben-il-volto-e-la-morte. on 4 April 2021.

13 The dichotomy of showing one's face and concealing it is epitomized in the techniques of masking. On this issue, see Gramigna 2021, Leone 2020. 


\section{Critique of the semiotic bias and the association of ideas in face recognition}

The words 'recognition' and 'to recognize' derive from the Latin 'recognoscere'. This term is composed of the prefix 're-', which means 'again', and 'cognoscere', which stands for 'knowing. Etymology suggests that to recognize someone or something is an action that entails that the object recognized (be it a human being or a thing) was seen or known by the subject in an earlier phase prior to the time when recognition occurs. In a nutshell, we recognize something known. As Ellis (1975: 409) writes, "recognition memory involves the identification of some previously experienced configuration or event". One thing emerges from this cursory description of terminology: recognition is bound up with the world of perception, and particularly with the field of vision. This also suggests the idea of a recursive element embedded in the concept of recognizing, which is, literally, knowing again, knowing for the second time. Firstly, a question that emerges immediately is whether there is a relation between memory and recognition and, if so, how can such a relation be qualified. Secondly, another issue concerns the uniqueness of the human face and whether it is processed by a special system as compared to the processing of objects that are not faces (Ellis 1986: 5).

Because the field of vision varies according to the distance in human interactions, the perception of the human face in social settings is regulated by the laws of proxemics. It is worth noting that in Edward T. Hall's typology of distances in humans, the face is perceived by others only at close distances. Outside the range of close distances, indeed, faces become blurred and unrecognizable. For Hall (1959: 115), "intimate distance" (less than 18 inches) - the distance of "love-making and wrestling" - is the distance where "sight (often distorted), olfaction, heat from another person's body, sound, smell, and the feel of the breath all combine to signal unmistakable involvement with another body" (Hall 1959: 116) and "personal distance" (from one to four feet) is the zone where people can touch each other and the field of vision is very sharp. At the close phase of personal distance, the face of the other indeed becomes very visible: "the planes and roundness of the face are accentuated; the nose projects and the ears recede; the hair of the face, eyelashes, and pores are very visible" (Hall 1959: 119). Whilst the idea of face visibility is present in Hall's classic account, this aspect was stressed with particular force in Krampen's revisitation of proxemics (Krampen 1995: 283-284).

Before venturing further, it is worth pointing out that some key ideas on face recognition, the cognitive bias, and the prejudices that lurk beneath it, can be gleaned from the debate between Johann Caspar Lavater and his fierce critic, the Göttingen physicist Georg Christoph Lichtenberg. In On Physiognomics: Against 
Physiognomists, published in 1777 (second ed. 1778), Lichtenberg delivers a series of sharp and penetrating points of criticism directed at the paradigm of physiognomy as advocated by Lavater. ${ }^{14}$ As Lichtenberg (1991: 107) himself pointed out, the true intention of his work is an admonition to treat such a theme with prudence because judging a person by the face may lead to gross mistakes and overgeneralizations. This is what today goes under the rubric of 'first impression' or 'face value' (Todorov 2017).

As Lichtenberg remarks:

[...] it is perfectly coherent with the laws of our thought and our sensibility that, as soon as we look at a man, suddenly a figure absolutely more resemblant than we have ever met comes to our mind. Usually, such a figure directly determines our judgment. We regularly make judgments on the base of the face, and we are regularly mistaken. (Lichtenberg 1991: 126) ${ }^{15}$

Lichtenberg's criticisms on physiognomy are numerous and acute and cannot be dismissed in a few words. One such item of criticism concerns the principle of the "association of ideas" that lays at the basis of the mechanism of matching faces to psychological traits based on a set of prior templates and assumptions the individual already has in stock. ${ }^{16}$ Lichtenberg argues that, in recognizing others, people project onto the face some pre-existent cognitive schemes that play a pivotal role in the perception and recognition of faces. As Lichtenberg writes, "The superficial physiognomist finds a face in every drop of ink and a meaning in every face" (Lichtenberg 1991: 127). ${ }^{17}$

The author explains how face recognition works in the following terms. Contra the tenets of physiognomy, Lichtenberg argues that the face is unfathomable in its entirety. For this reason and for the purpose of grasping a face, each of us creates an "extract" of it, a face's template. This extract is obtained on the basis of the

14 It would be very limited and inaccurate to say that Lichtenberg's polemical notes are levelled against Lavater. It is much more than that. Lichtenberg's critical remarks, instead, concerned the fashionable trend of physiognomics, superficial and without depth, that was rampant at the time when he lived. So, he was against the trivialization and popularization of physiognomy. 15 "E perfettamente coerente con le leggi del nostro pensiero e della nostra sensibilità che, non appena posiamo lo sguardo su un uomo, ci venga subito in mente la figura a esso in assoluto più somigliante che abbiamo già incontrato. Questa figura, di solito, determina direttamente il nostro giudizio. Regolarmente giudichiamo in base al volto, e regolarmente ci sbagliamo".

16 For a discussion of the criticisms that Lichtenberg launches at Lavater and to the "epidemics" of physiognomy, see Gurisatti 2006: 91-111, 1991: 24-40.

17 "[...] il fisiognomo superficiale in ogni macchia d'inchiostro trova un volto e in ogni volto un significato". 
interests, mood, and knowledge of the beholder, who assigns to it a host of different meanings (Lichtenberg 1991: 129). According to Lichtenberg, such a template is systematized so that each observer identifies a face composed of four dots, as depicted in the following image (Fig. 1):

Figure 1. Face template according to Lichtenberg (1991: 129).

Gurisatti's comments on Lichtenberg's principle of the association of ideas are illuminating:

\begin{abstract}
Physiognomy would lead to projecting onto the face contingent and predetermined cognitive-perceptive schemes, subjecting the face to a subjective (perhaps unconscious) strategy of codification and recognition. In short, the face would be neither explained nor understood - that is, known - but only re-cognized, that is to say made adequate and empathically homologated to cognitive habits, visual conventions, prejudices of the viewer. (Gurisatti 2006: 24) ${ }^{18}$
\end{abstract}

Such a thesis is also in line with the etymology of the term 'recognoscere', recalled earlier, which means recognizing something already known. The mechanism Lichtenberg discusses is likely to describe how certain cultural biases operate in guiding the recognition of others' faces. At this juncture, it is worth recalling Eco, who in Kant and the Platypus elaborated a quite sophisticated theory of recognizing unknown entities - Eco's case studies being Montezuma and the Aztecs gradually forming the concept of a horse after the first meeting with the Spaniards, as well as the polemic over the zoological classification of the platypus - by matching a pre-existing stock of knowledge in order to grasp and categorize something new or unknown (Eco 2000[1997]). Eco's account of 'cognitive type' and 'nuclear content'

18 "La fisiognomica indurrebbe a proiettare sul volto schemi cognitivi-percettivi contingenti e predeterminati, sottoponendolo unilateralmente a una strategia soggettiva (magari inconsapevole) di codificazione e riconoscimento. Il volto, insomma, non sarebbe né spiegato né compreso - ossia conosciuto - bensi soltanto ri-conosciuto, vale a dire adeguato e omologato empaticamente alle abitudini cognitive, alle convenzioni visive, ai pregiudizi di colui che guarda" (Gurisatti 2006: 24). 
seems in alignment with the point raised above, although Eco's purpose is not to make sense of the recognition of the face, but the perception and categorization of a novel and unknown entity.

\section{Attending to face-like templates: An inborn disposition or a learned habit?}

One of the first patterns we perceive as human beings when we are born is the face of another. The ability to perceive others in the environment - to discern between friends and foes, selves and others - as well as to detect and seek to predict their possible moves, plans, and intentions, is a set of skills that proved to be essential in the evolutionary history of humankind (Rhodes et al. 2011). Whether this is an inborn attitude or a learned skill is an open question that has generated much debate. Yet the perception and recognition of others through the face is of paramount importance. There is evidence that the ability to detect the face is a skill that appears at a very early stage after birth (Buiatti et al. 2019).

Traditionally, biologists, cognitive scientists, developmental psychologists, and researchers of artificial intelligence have had the most to say on the subject (Bruce 1988; Bruce, Young 2012; Buiatti et al. 2019; Leopold, Rhodes 2010; Reid et al. 2017). As Ernst Gombrich (1956: 103) writes,

[...] we respond with particular readiness to certain configurations of biological significance for our survival. The recognition of the human face, on this argument, is not wholly learned. It is based on some kind of inborn disposition. Whenever anything remotely face-like enters our field of vision, we are alerted and respond.

Although the debate around face perception does not fit squarely in a rigid schematism, for clarity's sake we can single out two opposite fronts: an innatist and a constructivist one. Whilst the former perspective conceives face perception as an innate disposition, constructivists argue that this is an ability that is learned (for reviews, see Guthrie 1995: 103-121). This issue is still unresolved and there is no general agreement around such matters. Let us be clear that there is no complete agreement among experts in this field of research. Several authors have ventured into the study of the subject reaching inconsistent and divergent conclusions, with different authors offering different opinions. The difference in judgments on the interpretation of this concept is due to the non-homogeneity of the criteria used by the scholars for its elucidation on each occasion. 


\section{Face as a type: Cultural filters of an evolutionary trait?}

Semiotic research that dealt with recognition as a cognitive problem (Eco 1968, 1973, 1997; Volli 1972) suggested that the process of recognition - especially the recognition of 'iconic signs' - implies the prior establishment of some cultural norms. Both Eco and Volli note that the phenomenon of recognition is not limited to the cognitive and perceptual dimension and suggest that there is an element of culture to it, which ought not to be overlooked. This could be termed as the culturalist approach to recognition. As Eco (1980[1973]: 55) pointed out, the recognition of iconic signs implies a handful of operations which can be summarized as follows:

(1) a given culture must define recognizable objects on the basis of some emergent features or traits of recognition;

(2) there must be a convention which establishes that certain graphic traits correspond to some of the traits of recognition and that some of these recognition traits of the object must always be present in the reproduction in order to recognize the object;

(3) another convention is necessary to establish the modalities of production of the correspondence between graphic traits and traits of recognition.

If we conceive of face recognition in terms of iconic signs, we could perhaps speculate that cultures provide given traits of recognition that would make up the stock of knowledge activated when recognition occurs.

Édouard Manet's painting Music in the Tuileries (1862) shows the unique experience of identifying face-like patterns in an image that depicts unrecognizable and featureless faces in the crowd (Fig. 2): 


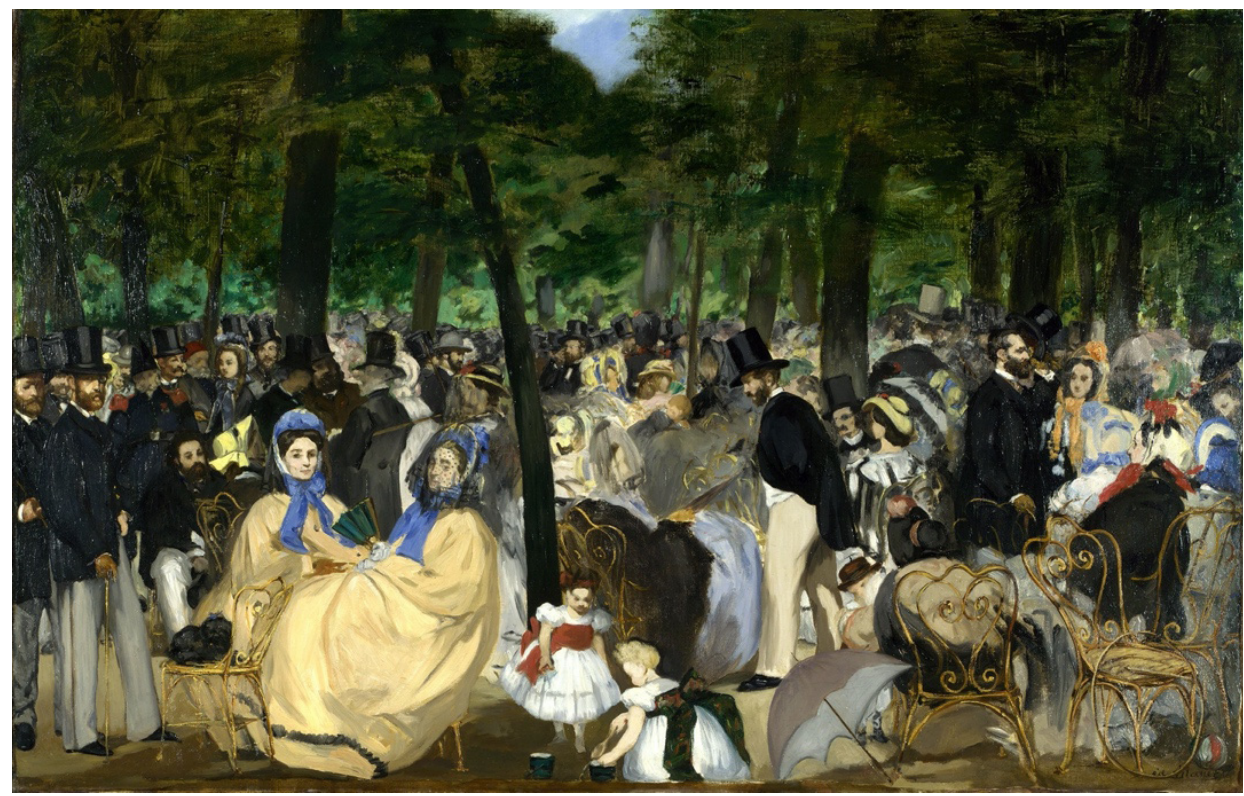

Figure 2. Édouard Manet. Music in the Tuileries (oil on canvas, 1862).

On the canvas, the plastic density of the painting and the gesture of the painter allow the beholder to experience a recognition based on spatial relationships. If too close or too far away from the work of art, the crowd will be blurred or even shapeless, but at the right distance, the viewer begins to recognize a series of visual patterns that result in the socio-historical characteristics of the face of the time. Likewise, Edgar Allan Poe, in his short story "The man of the crowd" (1840), describes the recognition of a human face from the absolute vagueness of anonymity of the crowd:

With my brow to the glass, I was thus occupied in scrutinizing the mob, when suddenly there came into view a countenance (that of a decrepit old man, some sixty-five or seventy years of age,) a countenance which at once arrested and absorbed my whole attention, on account of the absolute idiosyncrasy of its expression. Anything even remotely resembling that expression I had never seen before. I well remember that my first thought, upon beholding it, was that Retzch, had he viewed it, would have greatly preferred it to his own pictural incarnations of the fiend. [...] It was something even more intense than despair that I then observed upon the countenance of the singular being whom I had watched so pertinaciously. (Poe 1996[1840]: 392)

The example extracted from Poe's literary sensibility shows very poignantly how human faces can be categorized as types. Typification is the possibility of reading 
certain kinds of information from someone's face based on established and available sociocultural codes. As the Italian semiotician and expert in the field of face studies, Patrizia Magli (1995: 17) has pointed out,

The perception of a face is primarily based on its recognition. To recognize a face means to assign it to a class; and, in this respect, the perceptive experience seems already directed by the cultural filter: the filter of culture lies in between the face that is in front of us and our irresistible vocation to interpret. ${ }^{19}$

We do endorse Magli's view. Recognition and typification, then, are two phenomena that are, in some respect, interwoven. The constructions of types and their recognition by the observer are two processes that shed light on the sociocultural element in which both the phenomena of perception and recognition are enmeshed. From this perspective, typification is the process by means of which one selects certain aspects from a given token, and due to such selection, one is able to attribute the particulars of a face to the general category of humans as a group through an abstract interpretation. Indeed, typification is a classifying scheme that arises from the concrete practice of ordinary life, made up of interactions and problems to be solved in order to recognize someone. Such typifying schemes produce a structure on the basis of common knowledge that is not homogenous but contextually, and therefore culturally, distributed.

Originally, the distinction between type and token within semiotics comes from Charles Sanders Peirce, who introduced it in the essay "Prolegomena to an apology for pragmaticism" (1906). The type-token distinction is the cognitive process that leads to the construction of a model where the type is the class of which all signs are exemplars, and the tokens of a type are the occurrences, namely, the singular replicas that can be categorized in a given class. A type, as for instance a particular anatomical eye shape that can be read and interpreted as belonging to a specific ethnic group, must be actualized in a token, that is, in a singular face in order to be recognized. This face will be a sign of a type and, therefore, of the group to which the type refers. For instance, because of the contextual ideologies that have raged in the construction of nation-states, we are led to recognize the existence of a specific type of faciality according to cultural logic, such as there being no token of Italianity with specific traits other than Caucasian ones. However, the occurrences that crowd the globalized faciality together with the memories and texts of the past

19 "La percezione di un volto si basa innanzitutto sul suo riconoscimento. Riconoscere un volto significa assegnarlo a una classe; $e$, in questo senso, lesperienza percettiva sembra già orientata dal filtro culturale: tra il volto che ci sta di fronte e la nostra irresistibile vocazione a interpretare [...] si interpone il filtro della cultura." 
make manifest the existence of a whole series of facial occurrences that expand the pertinence of the type.

This process can be described as the extraction of types that are interpreted as forming a certain individuality depending on a social token, a strategy that enables the categorization of experience. Nevertheless, typification, as an interpretative activity, can be untied from the idea of an operation based on the established codification and selection of characteristics of a type projected on tokens, and leading it back to a continuous activity of token construction starting from the possibilities of the practical horizon in which they take root based on the pertinence. However, the daily socio-cultural experience can be compared with the facility of typecasting someone on the basis of social facial types that circulate in the cultural iconosphere. As Jessica Helfand (2019: 187) wrote: "To typecast is to color inside the lines, to proceed with expectations [...]. Habit is an unforgiving teacher [...]. What you see and what you respond to is the simulacrum, not the soul; the posture, not the person". Even today, with mobile applications and filters that lead us to manipulate our facial representations, we are primed to see faces as a territory conquered by the hegemonic-type beauty parameters that conduct stereotyping and bias: 'whitewashing, 'forever young', etc. We find two poles: the individual and his/her behaviour on the one side, the society and the typification of the behaviour of individuals on the other side. Under the influence of complex historical and social processes, specific forms of behaviour are formed, typifying what is accepted or rejected, what is lawful or forbidden, what is valuable or devoid of value. As indicated by Juri Lotman (2006), a complex semiotic norm of ethical, religious, aesthetic, practical and other kinds enters the cultural construction, against the background of which the identity of human behaviour is constituted.

In this sense, Lotman's semiotic model of culture can be read considering the category of enunciative practice. If the behavioural text is the result of the sedimentation of a series of individual acts, which make up a collective enunciative practice, the variations with which it is reproduced by the individual constitute an individual enunciative practice. The latter can strengthen the behavioural text through the repetition of the same sequence of behaviours, but it can also modify it by constituting a variation and modification of the given cultural patterns.

As aptly discussed in Giovanni Gurisatti's inquiry into the aesthetics of the face throughout history, physiognomy has generally been following two rather opposing tendencies. The first tendency strives towards typification. Typification is predicated upon the idea that the varieties of human appearances can be classified in terms of types. The second perspective conceives of the human face in terms of its uniqueness and individuality (Gurisatti 2006: 248). Likewise, Rudolf Kassner (1997: 40) differentiates between two different perspectives: the first being 
"constructivist", for it conceives of faces in terms of eyes, noses, mouths, and ears, and it begins with a concept to reach a type. This perspective highlights the form of the face as well as the fixed parts of the human face (Kassner 1997: 58). The second is "differential", for it focuses on the uniqueness of the expression of the face and is predicated upon individuality and the dynamic aspect of the face. This point is worth pondering. This thesis posits that the physiognomic literature dealing with the human face from Aristotle to Lavater, has dealt with the subject in terms of matching facial features to a given type through a process of codification and typification. In other words, the physiognomic approach, at least up to Lavater, tends to reduce the authenticity and the uniqueness of a face to a given type. The rupture of this paradigm occurs with the "new physiognomic" proposed by Kassner (1997). It is only within a constructivist approach to faces that the hypothesis of interpreting faces as types can come forth. As Kassner sharply writes, "Thus, types live, are real and vital in a rigid, predetermined, already codified world, in a certain sense four-dimensional. Or vice versa: in this rigid, predetermined, finite, eternally repeating world, there may be only types, not individuals" (Kassner 1997: 59). ${ }^{20}$

\section{Face and identity: The role of facial features in personal identification}

In the previous sections, we have dealt with face recognition and typification, and mentioned face and identity only en passant. We have hinted at the role of face identification, and this issue deserves further qualification. Personal identification is a much larger phenomenon in comparison to identification based solely on facial features. Face identification is not equal to personal identification tout court, although the face plays a pivotal role here. Indeed, as forensic anthropology, forensic medicine and forensic genetics have pointed out, the systems of personal identification are varied and not all the methods of personal identification are based on the identification of the face in order to establish the identity of the subject. However, it is undeniable that there are methods of personal identification that are based on the physiognomic study of the face, which is not surprising, given that the human face is a marker of personal identity.

Nevertheless, the identification of a person can occur not only through the physiognomy of an individual but also by means of other identification methods such as fingerprints, the chromatic map of the iris and the DNA. For this reason,

\footnotetext{
20 "Dunque i tipi vivono, sono reali e vitali, in un mondo rigido, predeterminato, già codificato, in un certo qual modo quadrimensionale. O viceversa: in questo mondo rigido, predeterminato, finito, eternamente ripetentesi, potrebbero esserci solo tipi, non individui."
} 
it must be specified that personal identification based on the face is only one of the methods of personal identification that embraces a much wider range of types of recognition, which also include automatic techniques for recognizing people. It is, therefore, a very vast and complex area. In this study, we will not deal with biometric recognition. The latter represents a type of automatic recognition from the first intuitions of Alphonse Bertillon, the head of the identification section of the Paris police, who, in the mid-19th century, had guessed that the measure of certain parts of the body - such as the length of the feet or fingers - could be used to identify criminals. To be sure, Bertillon identified eleven parameters. From the 19th century onwards, images became a standard and in 1882, he established the use of the signalment, a photographic system giving images ('mugshots') and detailed descriptions of persons being tracked. These signalments all had the same format, a card with a series of standard shots correlated by an equally standardized description. It was the invention of a taxonomic system based on biometric data that gave the face a statistical character.

Later, Francis Galton and E. R. Henry's discovery of fingerprints as an element of individual identification inaugurated the method of the archive and archiving as a way of collecting, storing, and cataloguing data relating to personal identification. In 1893 this method was replaced by fingerprinting and the statistical path was established: identity was ascertained on skin patterns, a body trace that increasingly weakened the power of the representation of the face. That is, faith in the expressivity and truthfulness of the face had diminished, and from the fingerprint we moved on to the recognition of the iris, which marked the passage to the face as a deposit of abstract and numerical information, which is the end of the most recent applications for facial recognition. Since Bertillon, the history of biometrics has made enormous advancements and biometric recognition has become one of the most advanced types of recognition, which is not without risks for the privacy of people, however (Gates 2011).

Let us leave aside biometric identification and let us discuss identification based on facial features. With regard to personal identification based on the physiognomic study of the face, there is an important corollary to consider. First, there are two methods that are based on physiognomic traits: (1) indirect comparison method, and (2) direct comparison method. ${ }^{21}$ The former technique consists of a comparative method which is based on the comparison of images of an individual's face that allows determining the identity between two subjects. By comparing multiple images, an "identity judgment" (Viciano, Capasso 2021: 181) is

21 Cf. Luigi Capasso, Identificazione personale fisionomica attraverso immagini, University of Chieti; available at https://docplayer.it/12549821-Identificazione-personale-fisionomicaattraverso-immagini.html. Also relevant is Falco 1923. 
formulated. The direct comparison method, as the previous one, is a comparative method that assesses the image of an unidentified subject against the image of a subject whose identity is known.

What needs to be stressed is that in both cases, the identification of identity is based on an analysis and study of photographic material of various sorts. Often, there is no possibility of direct observation of people's faces or anatomical structures. For this reason, personal identification based on the physiognomic study of the face works especially through images of faces - that is, representations of faces - which become the privileged material for the investigation. These images can be photographs or frames extrapolated from video recordings. This point is worth pondering, for it is by no means a minor detail.

From a methodological point of view, as well as from the perspective of epistemology and semiotics, this is a remarkable point because the personal identification process is often based on photographic representations and, therefore, on images of faces. It is our contention that this difference has not been sufficiently stressed. It is one thing to assess the identity of an individual on the basis of the recognition of the face in real-life settings and in face-to-face interactions. The identification of an individual on the basis of photographic evidence is a different type of business. In fact, in current practice, a photograph of the subject is sufficient to identify a subject as the history of the ID card shows. Therefore, we are dealing with photographic representation of the face and its quality and accuracy, which are important factors in assessing personal identity. Indeed, face-images have been used as tracking devices for identification. The history of the identity card has a longer history than the face-image, at least in France and Germany. Its origins date back to the late Middle Ages, and it contained descriptions of the owner.

As Lotman (1998: 63-64) pointed out, from the point of view of culturology, the function of proof of the authenticity of the subject was originally performed by the portrait that anticipated the role of photography. From the standpoint of semiotics, it is important to stress that it is not only the likeness of people's faces to their representations that matters - that is, matching the object to its model - be it a portrait, a photograph, a video and so forth. On the contrary, what is pivotal is that the recognition of likeness has a socio-cultural dimension which should not be overlooked, because recognizing a face as similar to another occurs in a given socio-cultural context. In this regard, Lotman provides examples of photographs that do not resemble the people portrayed, thus presenting a low degree of likeness between them. A caricature or a portrait could have a higher degree of likeness than a "bad photograph". Nonetheless, due to the cultural function assigned to photography as a marker of authenticity, a photograph will always be preferred as a 
means of personal identification over a handwritten sketch or a caricature (Lotman 1998: 65). Lotman thus rightly remarks that it is the "formal ability to be $a$ sign of likeness that fulfills a given conventional function" (Lotman 1998: 65).

Identification differs from recognition in one important respect. Identification is a byproduct of history and societal need of identifying specific individuals. There were times in history when people were neither identified nor identifiable. We would conceive of recognition as a quality that precedes identification biologically and historically.

\section{Machine face detection and the future of face recognition}

One important and fast-growing area of research within face perception is the research framework of face recognition by computers (Wechsler et al. 1998), which we will touch on only tangentially. In this study, we are mainly concerned with the way in which humans recognize faces, although machine face recognition is a fast-growing research field that should not be overlooked.

Today, the importance of face recognition, including the plethora of the nuanced meanings attached to this semantic field - identifying, classifying, filing, tracking, to mention but a few - has seen a re-emergence due to the widespread use of digital media, the innovations brought along by the increasing use of artificial intelligence of face detection, and technologies of tracking and personal identification. The establishment of advanced machine learning, artificial-intelligence-based algorithms and network-based, automated services have altered the way in which we thought of faces, provided some benefits and opened up new challenges. AI poses some serious questions of ethics and perpetuates social bias (O' Neil 2017). What in the past was generally thought of as a skill mastered through biological evolution and engrained in the genetic make-up of a species, today has become the hallmark of intelligent systems capable of performing complex operations that involve, to some extent, face recognition processes unheard of only a few years ago. In a nutshell, the way we conceive of faces has changed dramatically and opened up unprecedented scenarios.

The panorama we must face today is, therefore, complex and unprecedented. Human beings' lives have expanded and become digital (Turkle 1995; Windley 2005). The massive availability of big data and of public records - which range from images to geo-localized information - has radically altered the way in which the concept of face recognition has been traditionally conceived. Needless to say, as bodies of flesh and bones leave fingerprints, also digital selves leave many traces behind, which can be decoded, clustered, tracked and filtered for different 
purposes, including identification and recognition. Hence, new challenges lie ahead for the researchers: to unpack and contextualize a phenomenon that has taken on some very nuanced and unprecedented meanings.

From Woodrow Wilson Bledsoe's first tinkering in the $1960 \mathrm{~s}^{22}$ to the contemporary pervasiveness of facial detection systems in our daily life, both in the private and the public sphere, passing through the interaction with mobile phones through the border control services, all show the pervasiveness of this phenomenon. During the last twenty years, a considerable number of scholars and artists have focused on the opportunities and limits offered by artificial recognition technologies: the research of Kate Crawford and Trevor Paglen (2021), Kelly Gates (2011), Shoshana Amielle Magnet (2011), among others, together with the works of artists like Hito Steyler, Leonardo Selvaggio and Zach Blas show the relevance of these phenomena.

This pervasiveness can be surely understood as symptomatic of the facial society described by Thomas Macho and Gerburg Treusch-Dieter (1996) while, at the same time, it makes visible some continuities and discontinuities between artificial and human recognition systems and processes. The first difference concerns the question of the accessibility of the recognition. On the one hand, artificial vision recognizes human beings through an invisible operation inaccessible to most humans. On the other hand, human recognition, even though extremely complex both neurophysiologically and culturally, is a reciprocal experience within the human species. Except among those affected by prosopagnosia, as human animals, we recognize faces as being seen through our face. In both human and artificial recognition, the result of the process is the production of some kind of knowledge. However, the qualitative dimension of the information generated by artificial processes is under assessment of legitimacy, while in the case of human recognition it can be over-interpreted. An example in this direction can be emotion recognition. We are witnessing an increasing demand for emotion recognition in many fields of security such as government, public and private agencies, biomedicine or therapy (Dutta, Barman 2020). Still, doubts persist about the effectiveness of such a complex task, which is often flawed even in human recognition. These points of contact and distance mark some continuity and discontinuity in recognition processes. Many artificial recognition systems are inspired by human processes. In this regard, a task for the future of face recognition will be to ask to what extent artificial recognition replicates human cognitive processes and how these eventual replications relate to a discourse on the visual.

22 In 1963 Woodrow Wilson Bledsoe published the research entitled A Proposal for a Study to Determine the Feasibility of a Simplified Face Recognition Machine, one of the first studies to investigate the relationship between artificial intelligence and facial image recognition on behalf of the US Central Intelligence Agency. 


\section{Conclusion}

The present study has led towards a semiotics of recognition by unpacking the meaning of the human face under three different, yet complementary, aspects. We have limited our study to three main aspects, namely, recognition, identification and typification of faces, our strategy being to discover a network of relationships of meaning among these three aspects. The face as a recognizable pattern is engrained in the process of semiotic mediation (recognition). Of the three, recognition is the broadest phenomenon, for it includes the recognition of objects that are not limited to the recognition of human faces. This is probably also the oldest form of conceiving of faces that has a direct connection to the biology of face recognition. The face as the focus of personal identity (identification) uses faces as identity markers and is a scientific procedure invented by legal institutions to establish the genuine identity of people. Such a procedure is liable to falsification and opens up to the vast area of fake identities, simulation and fraud. The face thought of as a result of typification, that is, the possibility of reading certain kinds of information from someone's face based on established and available sociocultural codes, is a semiotic practice that dwells with the extraction of types on the basis of socio-cultural token (typification).

Acknowledgements: This reseach is part of a project that has received funding from the European Research Council (ERC) under the European Union's Horizon 2020 research and innovation programme (Grant agreement No 819649 - FACETS).

\section{References}

Agamben, Giorgio 2021. A che punto siamo? Lépidemia come politica. (Nuova edizione accresciuta.) Padova: Quodlibet.

Antonini, Giuseppe J. 1900. I precursori di Lombroso. Torino: Fratelli Bocca Edittori.

Baltrušaitis, Jurgis 1981. Lo specchio. Rivelazioni, inganni e science-fiction. Milano: Adelphi. Belting, Hans 2017. Face and Mask: A Double History. Oxford: Princeton University Press. Birdwhistell, Ray L. 1970. Kinesics and Context: Essays on Body-Motion Communication. London: Allen Lane - Penguin Press. https://doi.org/10.9783/9780812201284

Bottéro, Jean 1974. Symptomes, signes, écritures en Mésopotamie ancienne. In: Vernant, Jean Pierre et al. Divination et rationalité. (Recherches anthropologiques.) Paris: Seuil, 70-193.

Buiatti, Marco; Di Giorgio, Elisa; Piazza, Manuela; Polloni, Carlo; Menna, Giuseppe; Taddei, Fabbrizio; Baldo, Ermanno; Valortigara, Giorgio 2019. Cortical route for facelike pattern processing in human newborns. PNAS. Proceedings of the National Academy of Sciences of the United States of America 116(10): 4625-4630. https://doi.org/10.1073/ pnas. 1812419116

Bruce, Vicki 1988. Recognising Faces. New York: Routledge. 
Bruce, Vicki; Young, Andy 2012. Face Perception. New York: Psychology Press. https://doi. org/10.4324/9780203721254

Courtine, Jean-Jacques; Haroche, Claudine 1992. Storia del viso. Esprimere e tacere le emozioni (XVI-XIX). Palermo: Sellerio.

Crawford, Kate; Paglen, Trevor 2021. Excavating AI: The politics of images in machine learning training sets. AI \& SOCIETY: 1-12. https://doi.org/10.1007/s00146-021-01162-8

Damish, Hubert 1992. Lalfabeto delle maschere. In: Le Brun, Charles. Le figure delle passioni. Conferenze sull'espressione e la fisionomia. (Giuffredi, Maurizio, ed.) Milano: Raffaello Cortina, 102-116.

Darwin, Charles 1965[1872]. The Expressions of Emotions in Man and Animals. Chicago: The University of Chicago Press.

Dutta, Paramartha; Barman, Asit 2020. Human Emotion Recognition from Face Images. Singapore: Springer Nature. https://doi.org/10.1007/978-981-15-3883-4

Eco, Umberto 1968. La struttura assente. Milano: Bompiani.

Eco, Umberto 1975a. Volti di lupi, volti di agnelli. In: Johann Kaspar Lavater. Il Lavater Portatile. Tom. I. Milano: Moizzi Editore.

Eco, Umberto 1980[1973]. Segno. Milano: Mondadori.

Eco, Umberto 1984. Proposals for a history of semiotics. In: Borbè, Tasso (ed.), Semiotics Unfolding: Proceedings of the Second Congress of the International Association of Semiotic Studies, Vienna, July 1979. Vol. 1. (Approaches to Semiotics 68.) New York, Amsterdam: De Gruyter, 75-89. https://doi.org/10.1515/9783110869897-012

Eco, Umberto 2000[1997]. Kant and the Platypus: Essays on Language and Cognition. London: Vintage.

Eco, Umberto 2010. Sugli specchi ed altri saggi. Milano: Bompiani.

Edkins, Jenny 2015. Face Politics. New York: Routledge. https://doi.org/10.4324/ 9781315718040

Ellis, Hadyn D. 1975. Recognizing faces. British Journal of Psychology 66(4): 409-426. https://doi.org/10.1111/j.2044-8295.1975.tb01477.x

Ellis, Hadyn D. 1986. Introduction: Processes underlying face recognition. In: Bruyer, Raymond (ed.), The Neuropsychology of Face Perception and Facial Expression. New York: Psychology Press, 1-27.

Ekman, Paul 1978. Facial signs: Facts, fantasies, and possibilities. In: Sebeok, Thomas A. (ed.), Sight, Sound and Sense. Bloomington: Indiana University Press, 124-156.

Fabbri, Paolo 1995. Difformità del viso. In: AA.VV., Identità-Alterità. Figure del corpo 1895/1995. Biennale di Venezia, 46. Esposizione internazionale d'arte. Marsilio: Venezia.

Falco, Giuseppe 1923. Identità. Metodo scientifico di segnalamento e identificazione. Roma: Maglione \& Strini.

Galassi, Romeo; De Michiel, Margherita 1997. Il simbolo e lo specchio. Scritti della scuola semiotica di Mosca-Tartu. Napoli: Edizioni Scientifiche Italiane.

Gates, Kelly A. 2011. Our Biometric Future: Facial Recognition Technology and the Culture of Surveillance. New York, London: New York University Press. https://doi.org/10.18574/ nyu/9780814732090.001.0001

Gauthier, Isabel; Tarr, Michael J.; Moyan, Jill; Skudlarski, Pawel 2000. The fusiform "face area" is part of a network that processes faces at the individual level. Journal of Cognitive Neuroscience 1: 495-504. https://doi.org/10.1162/089892900562165 
Getrevi, Paolo 1991. Le scritture del volto. Fisiognomica e modelli culturali dal Medioevo ad oggi. Milano: Franco Angeli.

Ginzburg, Carlo 1986. Miti emblemi spie. Morfologia e storia. Torino: Einaudi.

Goffman, Erving 1956. The Presentation of Self in Everyday Life. Edinburgh: University of Edinburgh, Social Sciences Research Centre.

Goffman, Erving 1967. Interaction Ritual: Essays in Face-to-Face Behavior. New York: Doubleday.

Gombrich, Ernst 1956. Art and Illusion: A Study in the Psychology of Pictorial Representation. Princeton: Princeton University Press.

Gramigna, Remo 2021. Le forme della maschera. Aspetti semiotici della manipolazione del volto e della plasticità dell'apparenza. Lexia 37-38 (Volti Artificiali/Artificial Faces): 121-140.

Gurisatti, Giovanni 1991. Introduzione. In: Lavater, Johann Caspar; Lichtenberg, Georg Christoph, Lo specchio dellanima. Pro e contro la fisiognomica. Un dibattito settecentesco (Gurisatti, Giovanni, ed.). Padova: Il Poligrafo, 11-64.

Gurisatti, Giovanni 2006. Dizionario fisiognomico. Il volto, le forme, l'espressione. Macereta: Quodlibet.

Guthrie, Stewart Elliot 1995. Faces in the Clouds: A New Theory of Religion. Oxford: Oxford University Press.

Hall, Edward T. 1959. The Hidden Dimension. New York: Anchor Books Doubleday.

Helfand, Jessica 2019. Face: A Visual Odyssey. Cambridge: The MIT Press.

Husserl, Edmund 1965. Idee per una fenomenologia pura e pe una filosofia fenomenologica. Torino: Einaudi.

Ingold, Tim 2002. The Perception of the Environment: Essays on Livelihood, Dwelling and Skill. London, New York: Routledge.

Kassner, Rudolf 1997. I fondamenti della fisiognomica. Il carattere delle cose. Vicenza: Neri Pozza Editore.

Kosinski, Michal 2021. Facial recognition technology can expose political orientation from naturalistic facial images. Sci Rep 11(100). https://doi.org/10.1038/s41598-020-79310-1

Krampen, Martin 1995. Proxemics revisited - Look at the body. In: Tasca, Norma (ed.), Ensaios em Homenagem a/Essays in Honor of Thomas A. Sebeok. Cruziero Semiotico 22-25: 289-288.

Lavater, Johann Caspar; Lichtenberg, Georg Christoph 1991. Lo specchio dell'anima. Pro e contro la fisiognomica. Un dibattito settecentesto (Gurisatti, Giovanni, ed., intr.). Padova: Il Poligrafo.

Le Breton, David 2010. Antropologia del volto: Frammenti. In: Vinci, Daniele (ed.), Il volto nel pensiero contemporaneo. Trapani: Il Pozzo di Giacobbe, 67-83.

Le Brun, Charles 1992. Le figure delle passioni. Conferenze sullespressione e la fisionomia (Giuffredi, Maurizio, ed.). Milano: Raffaello Cortina.

Leone, Massimo 2020. From fingers to faces: Visual semiotics and digital forensics. International Journal for the Semiotics of Law 34: 579-599. https://doi.org/10.1007/ s11196-020-09766-x

Leopold, David A.; Rhodes, Gillian 2010. A comparative view of face perception. Journal of Comparative Psychology 124(3): 233-251. https://doi.org/10.1037/a0019460

Lichtenberg, Georg Christoph 1991. Sulla fisiognomica; contro I fisionomi. In: Lavater, Johann Caspar; Lichtenberg, Georg Christoph. Lo specchio dell'anima. Pro e contro 
la fisiognomica. Un dibattito settecentesto. (Gurisatti, Giovanni, ed., intr.) Padova: Il Poligrafo, 97-138.

Lotman, Jurij 1998. Il ritratto. In: Lotman, Jurij. Il girotondo delle muse: Saggi di semiotica delle arti e della rappresentazione. (Burini, Silvia, ed.) Bergamo: Moretti \& Vitali, 63-96.

Lotman, Jurij. 2006. Tesi per una semiotica della cultura. (Sedda, Franciscu, ed.) Roma: Meltemi.

Macho, Thomas; Treusch-Dieter, Gerburg 1996. Medium Gesicht. Die faciale Gesellschaft. Berlin: Elefanten-Press.

Magli, Patrizia 1995. Il volto e l'anima. Fisiognomica e passioni. Milano: Edizione CDE.

Magnet, Soshana Amielle 2011. When Biometrics Fail: Gender, Race, and the Technology of Identity. Durham: Duke University Press. https://doi.org/10.1515/9780822394822

Manetti, Giovanni 1993. Theories of the Sign in Classical Antiquity. Bloomington: Indiana University Press.

Mourad, Youseff 1939. La physiognomonie arab et le Kitāb al-Firāsa. Paris: Librairie Orientaliste Paul Geurhner.

Nöth, Winfried 1990. Alice's adventures in semiosis. Working Papers and Pre-publications 195, serie B. Urbino: Centro Internazionale di Semiotica e Linguistica, Università di Urbino.

Ogibenin, Boris L. 1975. Masks in the light of semiotics: A functional approach. Semiotica 13(1): 1-10. https://doi.org/10.1515/semi.1975.13.1.1

O’Neil, Cathy 2017. Weapons of Math Destruction: How Big Data Increases Inequality and Threatens Democracy. New York: Broadway Books.

Piras, Antonio 2010. Le parole del volto. Spigolature storico-linguistiche ai margini di un campo semantico. In: Vinci, Daniele (ed.), Il volto nel pensiero contemporaneo. Trapani: Il Pozzo di Giacobbe: 47-63.

Peirce, Charles S. 1906. Prolegomena to an apology for pragmaticism. The Monist 16(4): 492-546. https://doi.org/10.5840/monist190616436

Poe, Edgar Allan. 1996[1840]. The man of the crowd. In: Poe, Edgar Allan. Poetry, Tales and Selected Essays. New York: The Library of America, 388-396.

Reid, Vincent M.; Dunn Kristy; Young, Robert J.; Amu, Johnson; Donovan, Tim; Reissland, Nadja 2017. The human fetus preferentially engages with face-like visual stimuli. Current Biology 27: 1825-1828. https://doi.org/10.1016/j.cub.2017.05.044

Ricoeur, Paul 2005. The Course of Recognition. Cambridge: Harvard University Press.

Rhodes, Gillian; Calder, Andy; Johnson, Mark; Haxby, James V. 2011. Oxford Handbook of Face Perception. Oxford: Oxford University Press. https://doi.org/10.1093/ oxfordhb/9780199559053.001.0001

Ruesch Jurgen; Kees, Weldon 1959. Nonverbal Communication: Notes on the Visual Perception of Human Relations. Berkeley, Los Angeles: University of California Press.

Sebeok, Thomas A. 1972. Semiotica e affini. Versus. Quaderni di studi semiotici 3: 1-11.

Thorek, Max 1946. The Face in Health and Disease. Philadelphia: F. A. Davis Company.

Todorov, Alexander 2017. Face Value: The Irresistible Influence of First Impressions. Princeton, New Jersey: Princeton University Press. https://doi.org/10.1515/ 9781400885725

Turkle, Sherry 1995. Ghosts in the machine. The Sciences 35(6): 36-39. https://doi. org/10.1002/j.2326-1951.1995.tb03214.x

Viciano, Joan; Capasso, Luigi 2021. Contributions of facial imaging to human identification in forensic cases: A retrospective study (1996-2019) at the Operative Unit of 
Anthropology of the 'G. d'Annunzio' University of Chieti-Pescara (Italy). European Journal of Anatomy 25(S2): 179-192.

Volli, Ugo 1972. Some possible developments of the concept of iconism. Versus. Quaderni di Studi Semiotici 3: 14-30.

Wechsler, Harry; Phillips, Jonathon P.; Bruce, Vicki; Fogelman Soulié, Françoise; Huang, Thomas S. 1998. Face Recognition: Theory and Practice. Berlin, Heidelberg: Springer Verlag. https://doi.org/10.1007/978-3-642-72201-1

Windley, Phillip J. 2005. Digital Identity. O’Reilly Media.

\section{Заметки о семиотике распознавания лиц}

Способность воспринимать и опознавать других по лицам имеет ключевое значение. Умение различать друзей и врагов, своих и чужих, а также обнаруживать и прогнозировать их возможные шаги, планы и намерения - навыки, доказавшие свою важность в эволюционной истории человечества. Целью этого исследования является изучение проблемы распознавания лиц как семиотического явления. Охват работы ограничен распознаванием лиц человеком. Человеческое лицо анализируется в контексте пересечения биологических и культурных процессов. Мы утверждаем, что способность замечать сходство имеет социально-культурное измерение, которое не следует упускать из виду. Опираясь на замечания Георга Лихтенберга о физиогномии, мы обсуждаем критику семиотической предвзятости, ассоциацию идей и механизм типизации, связанный с распознаванием лиц. Типизация лиц рассматривается в контексте распознавания и идентификации лиц. Мы предлагаем считать их тремя градиентами значения, составляющими карту отношений между различными когнитивными операциями, участвующими в распознавании лиц.

\section{Tähelepanekuid nägude äratundmise semiootika kohta}

Teiste tajumine ja ära tundmine nende nägude põhjal on otsustava tähtsusega. Suutlikkus tajuda teisi keskkonnas viibijaid - teha vahet sõprade ja vaenlaste, omade ja võõrast vahel ning teha kindlaks ja püüda ennustada nende võimalikke edasisi samme, plaane ja kavatsusi, on oskuste kogum, mis on osutunud inimkonna evolutsiooniloos määravaks. Käesoleva artikli eesmärgiks on vaadelda nägude ära tundmise teemat semiootilise nähtusena. Uurimuse ulatus piirdub näo tajumisega inimese kui liigi poolt. Inimnägu analüüsitakse bioloogiliste ja kultuuriliste protsesside vahelisel lävel. Väidame, et kujutise äratundmisel on ühiskondlik-kultuuriline mõõde, millest ei tohiks mööda vaadata. Lähtudes Georg Lichtenbergi märkustest füsiognoomia kohta, käsitleme semiootilise eelhoiaku kriitikat, ideede assotsieerumist ja nägude äratundmisega seotud tüpifitseerimismehhanismi. Käsitleme neid kui kolme tähendusgradienti, mis kaardistavad nägude äratundmisega seoses kaalul olevaid erinevaid kognitiivseid operatsioone puudutava suhtevõrgustiku. 